\title{
OMICs approaches-assisted identification of macrophages-derived MIP- $1 \gamma$ as the therapeutic target of botanical products TNTL in diabetic retinopathy
}

Ning Wang ${ }^{1}$, Cheng Zhang ${ }^{1}$, Yu Xu ${ }^{1}$, Sha Li ${ }^{1}$, Hor-Yue Tan ${ }^{1}$, Wen Xia ${ }^{2}$ and Yibin Feng ${ }^{1 *}$

\begin{abstract}
Background: Inflammatory reaction in the dysfunction of retinal endotheliocytes has been considered to play a vital role in diabetic retinopathy (DR). Anti-inflammatory therapy so far gains poor outcome as DR treatment. This study aims to identify a novel therapeutic target of DR from the OMICs studies of a traditional anti-DR botanical products TNTL.

Methods: Hyperglycemic mice were treated with TNTL. The anti-hyperglycemic effect of TNTL was validated to confirm the biological consistency of the herbal products from batches. Improvement of DR by TNTL was examined by various assays on the retina. Next-generation transcriptome sequencing and cytokine array was used to identify the therapeutic targets. In vitro study was performed to validate the target.

Results: We observed that TNTL at its high doses possessed anti-hyperglycemic effect in murine type I diabetic model, while at its doses without reducing blood glucose, it suppressed DR incidence. TNTL restored the bloodretina barrier integrity, suppressed retinal neovascularization, and attenuated the retinal ganglion cell degeneration. Transcriptomic analysis on the retina tissue of hyperglycemic mice with or without TNTL revealed that the inflammatory retina microenvironment was significantly repressed. TNTL treatment suppressed pro-inflammatory macrophages in the retina, which resulted in the inactivation of endothelial cell migration, restoration of endothelial cell monolayer integrity, and prevention of leakage. Cytokine array analysis suggested that TNTL could significantly inhibit the secretion of MIP1Y from pro-inflammatory macrophages. Prevention of endothelial dysfunction by TNTL may be mediated by the inhibition of MIP1 $\gamma / C C R 1$ axis. More specifically, TNTL suppressed MIP1 $y$ release from pro-inflammatory macrophages, which in turn inhibited the activation of CCR1-associated signaling pathways in endothelial cells.
\end{abstract}

Conclusion: Our findings demonstrated that TNTL might be an alternative treatment to DR, and the primary source of potential drug candidates against DR targeting MIP1 $\gamma / C C R 1$ axis in the retinal microenvironment.

Keywords: Tang-Ning-Tong-Luo, Diabetic retinopathy, Inflammation, Endothelial dysfunctions, MIP1y/CCR1 axis, Retina macrophages

\footnotetext{
* Correspondence: yfeng@hku.hk

${ }^{1}$ School of Chinese Medicine, The University of Hong Kong, 1/F, 10 Sassoon

Road, Pokfulam, Hong Kong, S.A.R., China

Full list of author information is available at the end of the article
}

(c) The Author(s). 2019 Open Access This article is distributed under the terms of the Creative Commons Attribution 4.0 International License (http://creativecommons.org/licenses/by/4.0/), which permits unrestricted use, distribution, and reproduction in any medium, provided you give appropriate credit to the original author(s) and the source, provide a link to the Creative Commons license, and indicate if changes were made. The Creative Commons Public Domain Dedication waiver (http://creativecommons.org/publicdomain/zero/1.0/) applies to the data made available in this article, unless otherwise stated. 


\section{Background}

As one of the characteristic microvascular complications of diabetes mellitus (DM), diabetic retinopathy (DR) is the leading cause of vision loss in diabetic patients [1]. In particular, two studies on the incidence of $D R$ in Chinese patients indicated that the prevalence of DR in Hong Kong accounts for 24.8 and $39.2 \%$ at baseline [2]. DR initially consists of an early non-proliferative stage but progresses into proliferative DR mainly associated with hyperglycemia and glucose dyscontrol [3]. Vascular endothelial growth factor (VEGF) plays a crucial role in mediating the progression of DR [4]. VEGF is produced in the retina with hypoxia-inducible factor- $1 \alpha$ (HIF- $1 \alpha)$ as the responsible transcriptional factor. Accumulation of VEGF in retina stimulates the generation of neovascularization as well as leakage of neighboring capillaries, which contributes to the blurred vision and eventually retinal damage [5]. Given its critical role in the pathological progression of DR, anti-VEGF treatment has been used to reduce neovascularization, though both panretinal photocoagulation and vitrectomy are yet the firstline and effective available therapy for DR [6]. AntiVEGF treatment, majorly consisting of various antibodies to VEGF analogs, is useful but failed to be longterm economically affordable due to its considerable cost for DR patients. Moreover, chronic patients were found not well responsive to anti-VEGF treatment [3].

Inflammation has been considered as a central role player in the initiation and development of DR in DM patients. Of note, increasing clinical evidence has postulated the association between inflammation and clinical features of DR. Up-regulation of pro-inflammatory cytokines and chemokines, such as TNF $\alpha$, IL6, IL1 $\beta$, and MCP-1, were detected in plasma and vitreous samples of patients with DR [7]. Serum levels of pro-inflammatory TNF $\alpha(p=0.013)$, CRP $(p=0.002)$ and VEGF $(p=0.003)$ were significantly higher in Type II DM patients with DR than those without DR [8]. A study within American Africans with type I DM revealed that serum pro-inflammatory factor TNF $\alpha$ was correlated with the prevalence of DR $(p<0.001)$, proliferative DR $(p<0.001)$ and the incidence of diabetic macular edema (DME) $(p<0.001)$ [9]. Meanwhile, pro-inflammatory TNF $\alpha$, IL6, IL1 $\beta$, IL8, and sIL2R levels significantly increased during the progression of non-proliferative DR towards proliferative DR [10]. The early inflammation-related events in DR involved the release of pro-inflammatory cytokines and adhesion of leukocytes to the retinal vasculature, lead to compromised vascular cells, tight junctions, and consequently, vascular leakage [11]. Increasing lines of evidence have revealed that inflammation in the retina was caused by hyperglycemia, the leading risk factor of DR in DM [12]. High glucose-induced activation of the resident and structurally-essential cells in the retina, is now known to be the facilitator of an inflammatory reaction during DR initiation [13]. Unfortunately, outcomes of trials of localized and systemic treatment using currently available anti-inflammatory agents remain controversial and discouraging. Developing novel anti-inflammatory treatments for DR is necessarily urgent.

In this study, we used multiple OMICs approaches to identify the novel therapeutic target in the treatment of diabetic retinopathy by a herbal product Tang-NingTong-Luo (TNTL). TNTL has been clinically used as traditional Chinese Miao medicine for centuries to treat diabetic-like symptoms of indigenous people in the mountain area. We observed that high doses of TNTL might possess hypoglycemic effects, while at nonhypoglycemic doses, TNTL was able to suppress DR incidence and progression in type I diabetic murine model. Transcriptomic analysis was then performed to identify the global change of retinal gene expression after TNTL treatment. Gene ontology and pathway analysis revealed that TNTL primarily suppressed inflammation in the retina of diabetic mice. Histological analysis showed that TNTL reduced the presence of inflammatory macrophages in the retina, and resulted in inactivation of endothelial cells. Cytokine profile analysis suggested that suppression of MIP1 $1 \gamma$ release from macrophages by TNTL may contribute to its inhibitory effects on endothelial dysfunction. Our present study suggests that TNTL may be an alternative treatment for DR, and a potential lead for the discovery of novel anti-inflammatory agents that are suitable for DR treatment.

\section{Materials and methods Preparation of TNTL}

TNTL is an ethnomedical formula commonly used in traditional Chinese Miao medicine by the indigenous people in mountainous areas of southwestern China. It was composed of Plantagins Herba (Cheqiancao in Chinese), Lonicerae Flos (Shanyinghua in Chinese), Agrimoniae Herba (Xianhecao in Chinese) and Trichosanthis Radix (Tianhuafen in Chinese). Production of TNTL was performed in GMP manufacturing in Bailing Pharmaceutical Co. (Guizhou, China).

\section{Cell line and cell culture}

Retinal Endothelial Cells (RECs) were purchased from Sciencell. RECs were cultured in Endothelial Cell Medium (Sciencell, USA) with 5\% fetal bovine serum, $1 \%$ endothelial cell growth supplement and $1 \%$ penicillin/streptomycin solution at $37^{\circ} \mathrm{C}$ incubator with $5 \% \mathrm{CO}_{2}$.

\section{Animal study}

Protocols of animal study were reviewed and approved by the Committee on the Use of Live Animals in Teaching 
and Research of the University of Hong Kong. Streptozotocin (STZ)-induced hyperglycemic mice were utilized as type I diabetic-like model associated with retinopathy. The 10 -week $\mathrm{C} 57 / \mathrm{BL} / \mathrm{J}$ male mice received 5 constitutive intraperitoneal injections of 50 $\mathrm{mg} / \mathrm{kg} \mathrm{STZ}$ in a citric buffer ( $\mathrm{pH} 4.5)$. Five days after the last injection, $4 \mathrm{~h}$-fasting blood glucose (FBG) was determined, and only FBG within 15.0 to $20.0 \mathrm{nmol} / \mathrm{L}$ were included. Mice only injecting citric buffer was used as normal control. Hyperglycemic mice were randomized into 5 groups: model, insulin treatment, and three TNTL treatment groups. For insulin group, mice received a daily injection of insulin $(0.1 \mathrm{U} / 10 \mathrm{~g}$ b.w., i.p.). For TNTL treatment groups, mice received different doses of TNTL solution in water $(0.9,1.8$, and $3.6 \mathrm{~g} / \mathrm{kg}$ b.w./day) via gavage. Normal and model groups of mice received the same volume of water. Treatment lasted 4 weeks. Body weight and random blood glucose were tested weekly. At the end of this experiment, FBG and glucose tolerance tests were performed. To measure glucose tolerance, mice were fasted for $12 \mathrm{~h}$ and then received $2 \mathrm{~g} / \mathrm{kg}$ b.w. glucose via intraperitoneal injection. The blood glucose level at 0, 30, 60, 90, and $120 \mathrm{~min}$ post-injection was determined and plotted. Evans blue assay was used as a direct indicator of retinal vascular leakage. Evans blue was intravenously injected to the mice and dye leakage onto the retina due to blood-retinal barrier breakdown was determined by dissecting the retina and extraction of Evans blue dye according to our previous publication [14]. The area under the curve of the plot was calculated. Serum was collected, and HbAlc was measured according to the manufacturer's instruction.

\section{Histology and retinal vascular preparation}

Eyeballs were collected from sacrificed mice. The retina was enucleated and placed on $4 \%$ paraformaldehyde overnight. The fixed retina was dehydrated and embedded. $4 \mu \mathrm{m}$ paraffin section of the retina was stained with hematoxylin and eosin dye for histological measurement. For retinal vascular preparation, the fixed retina was digested with $3 \%$ of trypsin dissolved in $0.1 \mathrm{M}$ Tris buffer $(\mathrm{pH}=8.2)$, and the preserved vascular architecture was stained with hematoxylin-eosin dye and imaged under 400x magnification by a digital camera (CoolSNAP) linked to the microscope (LEICA). The number of endothelial cells/pericytes and acellular capillaries were quantified in each sample.

\section{Wholemounting}

Survival RGCs were labeled by specific markers RBPMS and Tuj1 following a previous procedure with modifications $[15,16]$. Briefly, after mice were anesthetized by intraperitoneal injection of pentobarbital $(200 \mathrm{mg} / \mathrm{kg})$, eyeballs were enucleated and immediately fixed in $4 \%$ paraformaldehyde (PFA) for $24 \mathrm{~h}$. Afterwards, eyecups were taken out and post-fixed in 4\% PFA for $6 \mathrm{~h}$ followed by making four cuts to lie flat the retina as whole-mount tissue. Retinas were slightly rinsing five times in PBS for 10 mins per wash and then incubated in 3\% Triton X-100 / 2\% DMSO mixture (Sigma-Aldrich, St. Louis, MO) in PBS for 3 days at $4{ }^{\circ} \mathrm{C}$. Then, retinas were moved to blocking solution, including $10 \%$ goat serum and 3\% Triton X-100 in PBS, at room temperature for $4 \mathrm{~h}$. Afterwards, retinas were immunostained with the antibody BIII-tubulin (Tuj1) and RBPMS respectively (1:300, Abcam, USA). Sites that bound to primary antibody were visualized by incubating with Alexa Fluor 488 or 568-conjugated antibodies to corresponding IgG (1:500, Invitrogen, USA) for $6 \mathrm{~h}$, respectively. Following the final rinsing (PBS for 2 times), retinas were whole flat-mounted on glass slides with RGC layer up. RBPMS/Tuj1-double positive cells in RGC layer are identified as survival RGCs. Image $J$ was applied for counting $\mathrm{RBPMS}^{+} / \mathrm{Tuj} 1^{+} \mathrm{RGC}$ cells from eight random fields taken from four angles of the retina $\left(0^{\circ}, 90^{\circ}, 180^{\circ}\right.$, and $\left.270^{\circ}\right)$, four at both $1 \mathrm{~mm}$ and $2 \mathrm{~mm}$ from the optic nerve head respectively. Each selected area was $0.076 \mathrm{~mm}^{2}(250 \times 250 \mu \mathrm{m})$. All images were captured by a confocal laser microscope (200×, Carl Zeiss LSM 780, USA).

\section{Transcriptomic analysis and bioinformatics study}

Total RNA was isolated from the retina tissue of hyperglycemic mice with or without TNTL treatment using RNeasy mini kit (Qiagen, Germany). The total RNA was then subject to library construction and transcriptomic analysis (Exiqon, Denmark). The original data of mRNA sequencing was then uploaded to NetworkAnalyst platform for further analysis (https://www.networkanalyst. ca) [17-20]. Differential analysis of the normalized gene expression was performed with DESeq2. Genes with a significant change in expression (adjusted $p$-value $<0.05$, $\log 2$ (fold change) $>1$ ) were shortlisted for the generation of heatmap and volcano plot, as well as the analysis of protein-protein interaction network and gene set enrichment analysis (GSEA). Gene ontology (GO) and KEGG pathway analysis were performed on DAVID platform (https://david.ncifcrf.gov/home.jsp) with common genes of the three retrieved lists.

Bone marrow-derived macrophages (BMDMs) preparation BMDMs were prepared according to our previous publication [21]. In brief, cell suspension from femurs of C57/BL/J mice was collected with Ficoll method and induced for differentiation with murine recombinant macrophage-colony stimulating factor (M-CSF, $10 \mathrm{ng} /$ $\mathrm{mL}$ ) in RPMI1640 medium supplemented with $10 \%$ FBS. After 7-day of stimulation, BMDMs were induced into pro-inflammatory phenotype after addition of IFNY 
(20 ng/mL) and lipopolysaccharide (LPS, $100 \mathrm{pg} / \mathrm{mL}$ ) for $18 \mathrm{~h}$. Prepared cells were then treated with TNTL.

\section{Migration assay}

REC cells were seeded onto the apical side of transwell inserts (Corning, $8.0 \mu \mathrm{m}$ pore size) with $150 \mu \mathrm{l}$ serumfree medium. $750 \mu \mathrm{l}$ serum-free medium containing indicated cytokines or collected cell supernatants were added to the receiving chamber and incubated for $6 \mathrm{~h}$. Cells retained on the apical side of the insert membrane were removed, whereas cells at the basolateral side were fixed in $4 \%$ paraformaldehyde and stained with crystal violet. Images of migrated cells were captured under a light microscope.

\section{Barrier function assay}

The function of endothelial cells was tested by Transepithelial/Transendothelial Electrical Resistance (TEER) and leakage of FITC-Dextran through the endothelial monolayer. RECs were seeded on the apical side of transwell inserts (Corning, $0.4 \mu \mathrm{m}$ pore size) and grown until full confluence. The endothelial monolayer was incubated with culture supernatant of treated BMDMs for $48 \mathrm{~h}$. TEER of the endothelial monolayer was tested by Ohm's Law Method as described previously [22]. To test the endothelial monolayer leakage, $25 \mu \mathrm{g} / \mathrm{ml}$ FITC-Dextran (40 K, Sigma, USA) was added to the apical side of the monolayer followed by $24-\mathrm{h}$ incubation. The concentration of FITC-Dextran at the upper and receiving chambers was determined by a luminescence spectrometer with excitation wavelength at $494 \mathrm{~nm}$ and emission wavelength at $518 \mathrm{~nm}$. The percentage of FITC-Dextran leaked into the receiving chamber through the cell monolayer indicated the leakage after treatment [14].

\section{Quantitative real-time polymerase chain reaction (qRT- PCR)}

Total RNA was extracted by Trizol (Takara, Japan) and cDNA was synthesized from total RNA with first strand synthesis kit (Takara, Japan). The mRNA expression of target genes was quantitatively measured with SYBR Green reagents (Takara, Japan) on the LC480 platform (Roche, USA). Targeted genes expression data were normalized by the expression level of $\beta$-actin. Primer sequence would be available upon request.

\section{Immunoblotting}

Protein was extracted with RIPA buffer. $30 \mu \mathrm{g}$ total protein was loaded onto SDS-PAGE and separated by electrophoresis. Separated proteins were then transferred to PVDF membrane followed by blocking with 5\% BSA in TBST buffer $(25 \mathrm{mM}$ Tris- $\mathrm{HCl}, 137 \mathrm{mM} \mathrm{NaCl}$, and $2.7 \mathrm{mM} \mathrm{KCl}$, $0.05 \%$ Tween-20, $\mathrm{pH} 7.4 \pm 0.2$ ) for $2 \mathrm{~h}$ at room temperature. Membranes were then incubated with primary antibody of interests overnight at $4{ }^{\circ} \mathrm{C}$ and appropriate secondary antibody for $2 \mathrm{~h}$ at room temperature. The membrane was probed with ECL select substrate (GE Healthcare, Germany) on the Chemidoc chemiluminescent platform (Biorad, USA).

\section{Statistical analysis}

For the animal study, the sample size was 6 in each group; for in vitro experiment, studies were performed in triplicate. Data was present in mean $\pm \mathrm{SD}$. For multiple group comparison, differences were measured with an ordinary two-way ANOVA with LSD multiple comparisons, while for comparison between two groups, differences were measured with student t-test. $p<0.05$ were considered as statistically significant.

\section{Results}

High dose treatment of TNTL improved hyperglycemia in diabetic mice

Several previous studies have proven that TNTL improved insulin sensitivity and reduced blood glucose in type II diabetic models [23, 24]. To ensure the biological similarity of TNTL between batches, we firstly systemically evaluated the anti-hyperglycemic effect of TNTL on insulin-deficient type I diabetic model. Mice were continuously injected with a low dose of STZ $(55 \mathrm{mg} / \mathrm{kg}$, i.p.) for 5 days, and those with FBG within 15 to 20 $\mathrm{mmol} / \mathrm{L}$ were treated with different doses of TNTL. It was found that oral TNTL treatment had minimal impact on the body weight of diabetic mice (Fig. 1a) but exhibited the dose-dependent manner in reducing the random blood glucose (RBG) of diabetic mice (Fig. 1b). While the lower dose of TNTL $(0.9 \mathrm{~g} / \mathrm{kg}$, TNTL-L) showed no significant effect on the RBG of mice; medium and high doses ( 1.8 and $3.6 \mathrm{~g} / \mathrm{kg}$, TNTL-M and TNTL-H, respectively) could suppress the increase of blood glucose. 4-week treatment of TNTL at 1.8 and $3.6 \mathrm{~g} / \mathrm{kg}$ significantly reduced the FBG, and this effect appeared to be compatible with insulin treatment (Fig. 1c). Further analysis of the glucose intolerance of mice showed that TNTL treatment at 1.8 and $3.6 \mathrm{~g} / \mathrm{kg}$ significantly enhanced the tolerance of mice to glucose (Fig. 1d). Furthermore, TNTL dose-dependently reduced the plasma level of HbA1c, a marker used for risk estimates of diabetic complications (Fig. 1e). These data suggested that different batches of TNTL maintained consistent quality with similar biological activities, and this batch of herbal products was suitable for further experiment.

\section{TNTL suppressed the progression of DR independent to its anti-hyperglycemic effect}

DR is the major microvascular complication in diabetic patients. Proper glycemic control in patients with diabetes mellitus correlates to the amelioration of DR 


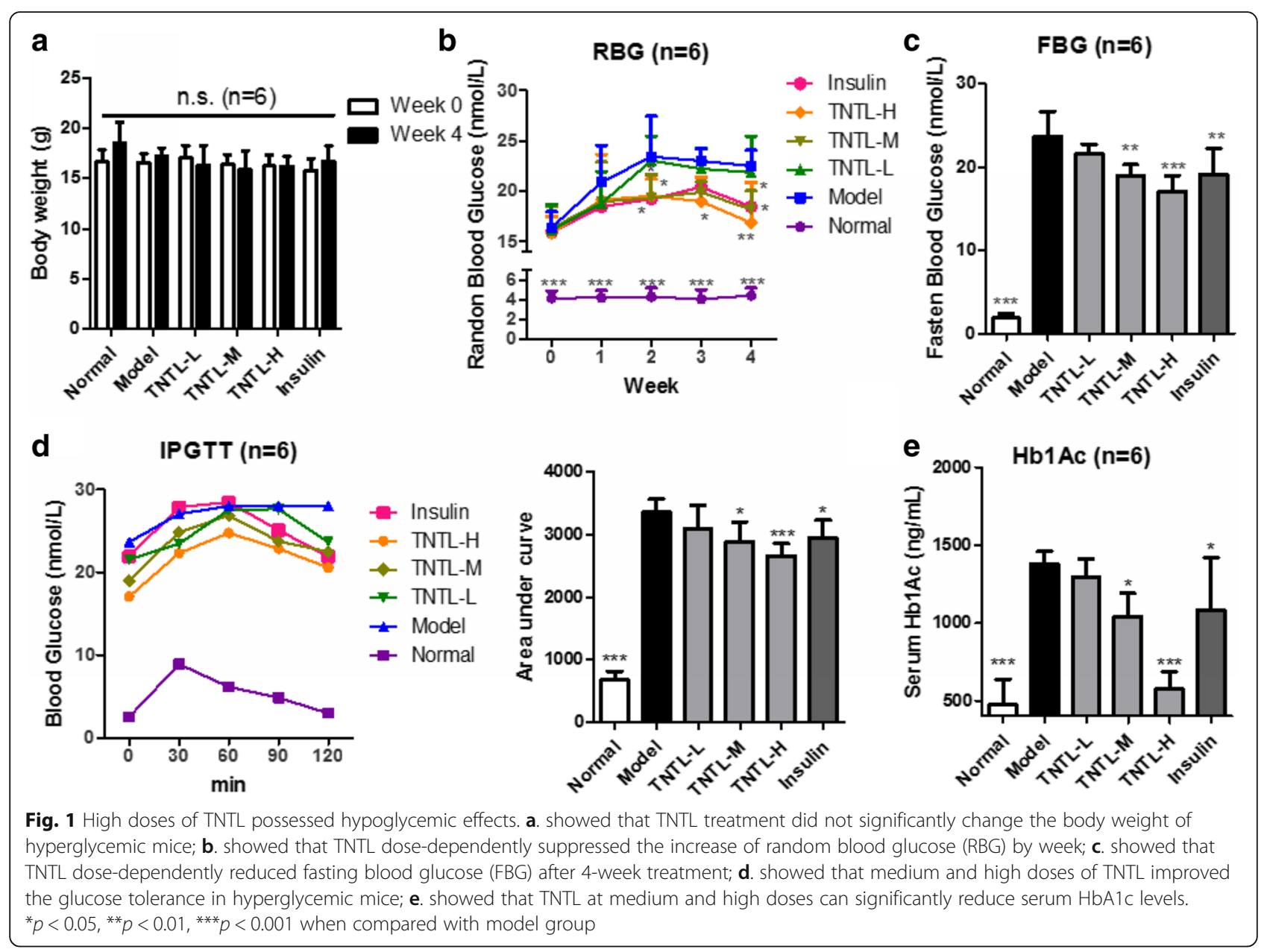

incidence [25]. Retinal vasculature was prepared and imaged (Fig. 2a), and the result showed that TNTL treatment, even at a low dose $(0.9 \mathrm{~g} / \mathrm{kg})$, was capable of reducing the endothelial dysfunctions during DR progression, as characterized by increased acellular capillaries (Fig. 2b) and the endothelial cell-to-pericyte ratio (Fig. 2c). To observe whether TNTL improved the retina condition in type I diabetic mice, blood-retina barrier leakage was tested. It was showed that TNTL could dose-dependently recover the blood-retina barrier and prevent the leakage of circulating Evan blue dye into the eyes. TNTL at a lower dose failed to control hyperglycemia in mice, but its effective action in preventing the leakage indicated that the effect of TNTL in retarding DR progression might be independent to glycemic control (Fig. 2d). Furthermore, as the vision loss during progressive DR is directly associated with retinal neuron degeneration [26], we measured the integrity of retinal ganglion cells in mice with or without TNTL treatment. It was shown that TNTL treatment could potently maintain the number of ganglion cells in the retina of diabetic mice, which further confirmed the inhibition of DR progression induced by TNTL treatment (Fig. 2e). Also, we used double staining of two markers, Tuj1 and RBPMS, in the vertically sectioned eyecup slides and whole-mounted retina. Tuj1 is a neuron marker and was used to identify retinal ganglion cells [27]. RBPMS was recently identified as a specific marker of retinal ganglion cells in rodents (mice, rats, rabbits, and Hartley guinea pigs) $[28,29]$ as well as in cats and monkeys $[29,30]$. Specifically, RBPMS was recently used to recognize retinal ganglion cells in the samples from patients with diabetic retinopathy [31]. It was shown that the Tuj1- and RBPMS-positive cells were mostly overlapped and located at the ganglion cell layer, which was consistent with a previous report [16]. In hyperglycemic mice, Tuj1/RBPMS-positive cells were significantly reduced compared with normal mice. TNTL treatment could remarkably recover Tuj1/RBPMS-positive cells in the retina. Observation in both vertically sectioned eyecup slides and whole-mounted retina was consistent (Fig. 2f \& g). These data suggested that TNTL may be able to prevent the incidence and progression of DR independent to glycemic control. 


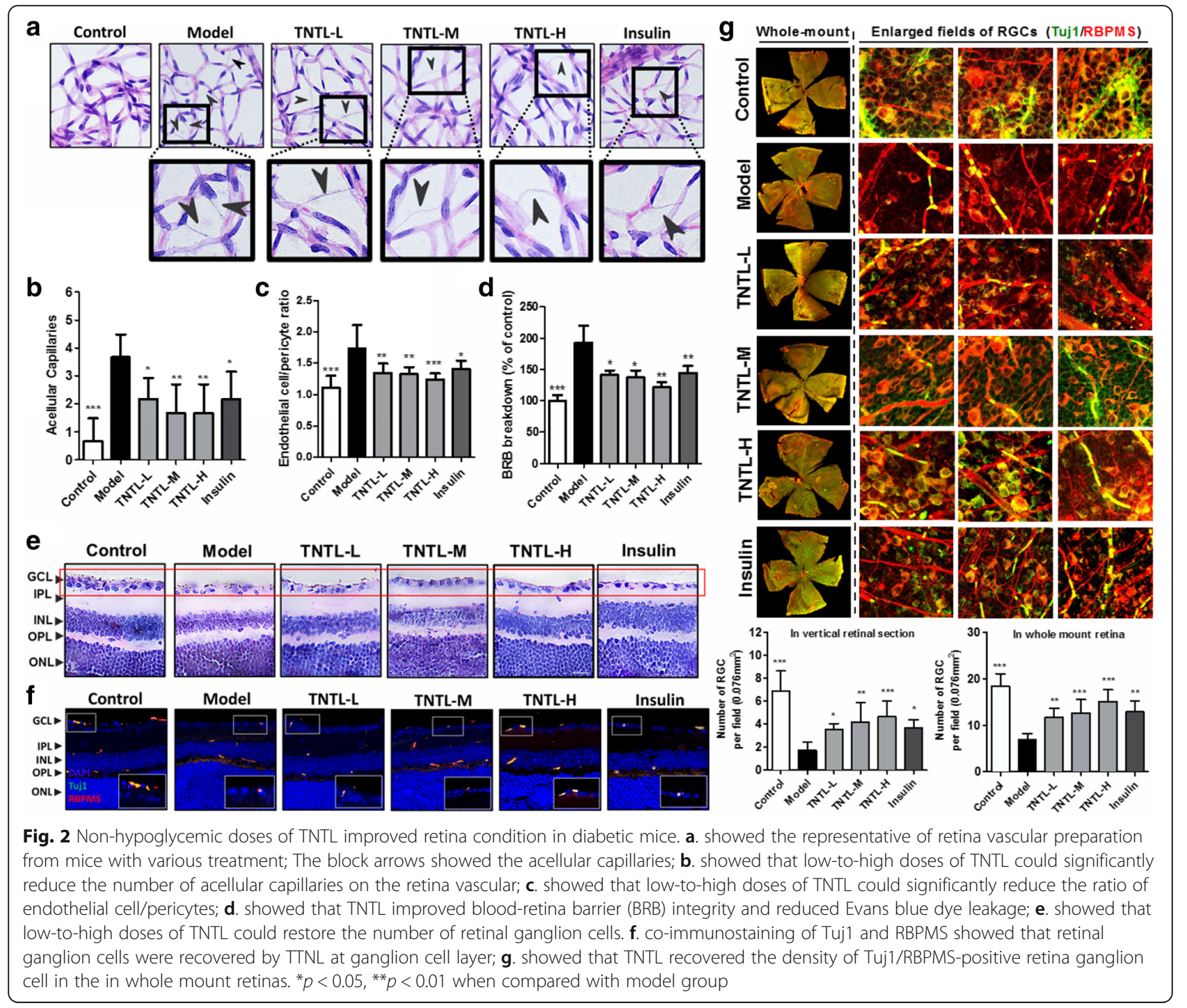

Inhibition of DR progression by TNTL involved its regulation on retinal inflammation

The initiation of DR, as well as its progression and endstage vision loss, involves several physiopathological mechanisms such as biochemical, endocrine and hemodynamic anatomical alterations, which they interact with each other in a time sequence [32]. Among these changes, inflammation has been considered as a central role player in the initiation and development of DR in DM patients. Accumulating clinical evidence have proven the association between inflammation and clinical features of DR. To further understand the targeted molecules that involve in the regulation of retinal microenvironment by TNTL in hyperglycemic mice, we isolated retina from hyperglycemic mice treated with or without TNTL, and implemented transcriptomic analysis on the gene expression within retina tissues. It was showed that TNTL treatment could significantly induce a change of expression to a series of retina genes (Fig. 3a \& b). Enrichment on the biological process (BP), cellular components (CC) and molecular functions (MF) related to expression change of the genes revealed that most of these genes play a common role in inflammation-related actions (Fig. 3c, highlighted with a red asterisk). Further analysis of TNTL-regulated signaling pathways on diabetic retina confirmed the involvement of inflammation-associated pathways (Fig. 3d, highlighted with a red asterisk). Also, by constructing the interaction network of proteins encoded by TNTL-altered retina genes, we observed that proteins associated with TNTL intervention played a key role as nodes in the construction of protein-protein interaction network related to inflammation (Fig. 3e). GSEA analysis further proved that TNTL treatment was prone to suppress inflammatory-related gene expression in the retina of hyperglycemic mice (Fig. 3f). These findings suggested 


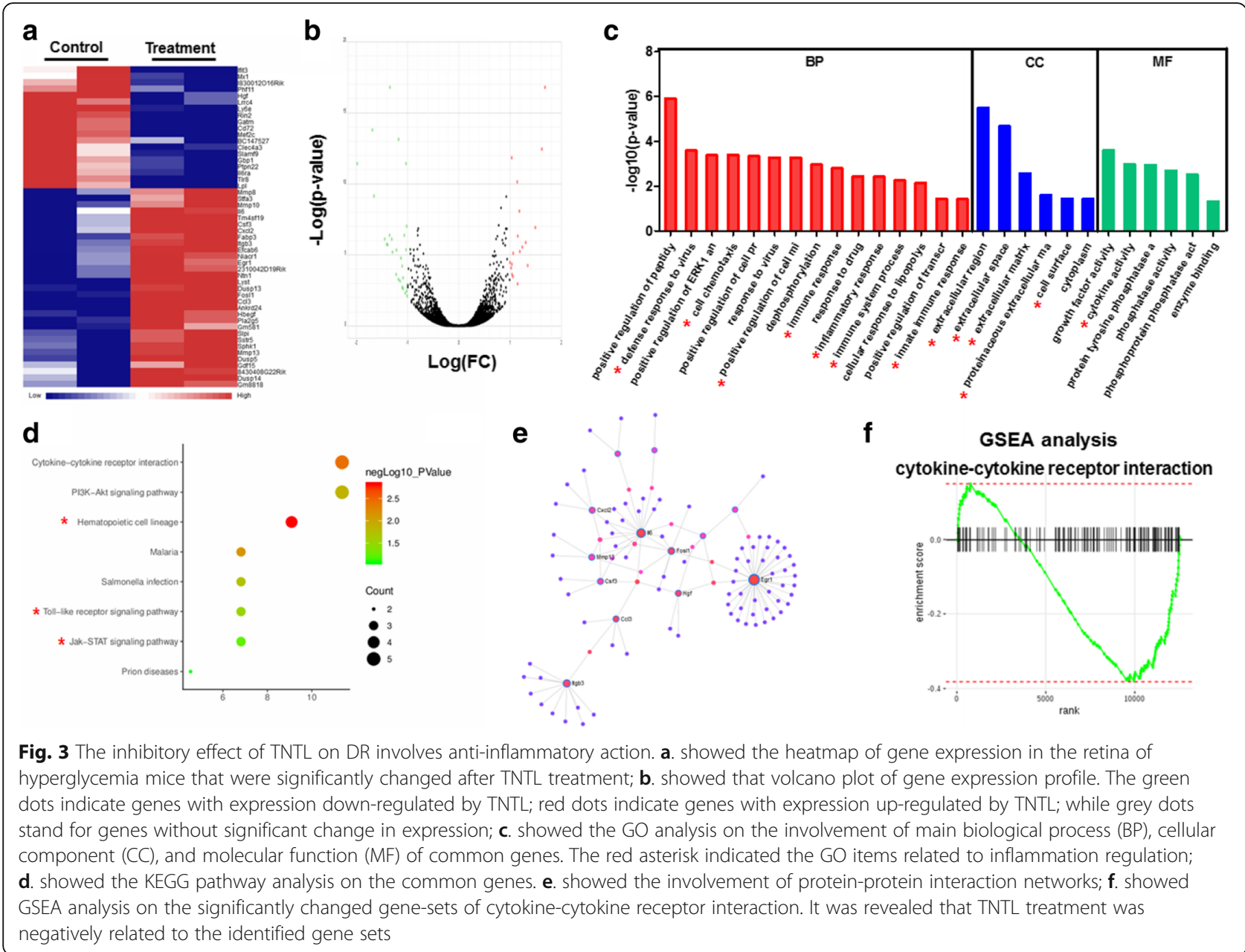

that inhibition of DR by TNTL may involve its regulation on the pro-inflammatory retinal microenvironment.

\section{Macrophage suppression by TNTL prevented endothelial} dysfunction in the retinal microenvironment

Inflammation in the retinal microenvironment was majorly contributed by the infiltration of macrophages and release of pro-inflammatory cytokines [33]. To examine whether TNTL suppressed inflammation in the retinal microenvironment, immunofluorescence staining of macrophage marker F4/80 was applied on the retinal section. It was found that in the retina of hyperglycemic mice, resident and infiltrated macrophages were accumulated at the apical and basolateral sides of the inner nuclear layer, and TNTL treatment significantly reduced the macrophages population in the retina, indicating that the inflammatory microenvironment of the retina in hyperglycemic mice was suppressed (Fig. 4a). To understand if suppression of macrophage by TNTL contributes to its improvement on the retinal endothelial condition, pro-inflammatory BMDMs induced by IFNy $(20 \mathrm{ng} / \mathrm{mL})$ and LPS $(100 \mathrm{pg} / \mathrm{mL})$ was treated with TNTL
(20 $\mathrm{mg} / \mathrm{mL}$ in water as a vehicle). The supernatant (SN) collected from BMDMs treated with or without TNTL was used to challenge RECs. It was shown that RECs cultured with TNTL-treated BMDMs derived SN had no significant difference on cell viability compared with RECs cultured with vehicle-treated BMDMs derived SN (Fig. 4b) but showed a potent reduction in motility (Fig. 4c). Furthermore, RECs monolayer cultured with TNTL-treated BMDMs derived SN exhibited higher integrity and lower leakage of FITC-dextran (Fig. 4d \& e). TNTL itself shown the minimal effect on the migration, permeability, and integrity of RECs (Fig. 4c-e). As increased migration and loss of monolayer integrity indicated the endothelial dysfunction in the diabetic retina, these data suggested that the suppression of pro-inflammatory macrophages by TNTL may be involved in the prevention of endothelial dysfunction and DR progression.

\section{Suppression of MIP1 $\gamma / C C R 1$ axis by TNTL contributed to the prevention of retinal endothelial dysfunction}

To further explore the underlying anti-inflammatory mechanism of TNTL in preventing endothelial dysfunction in 


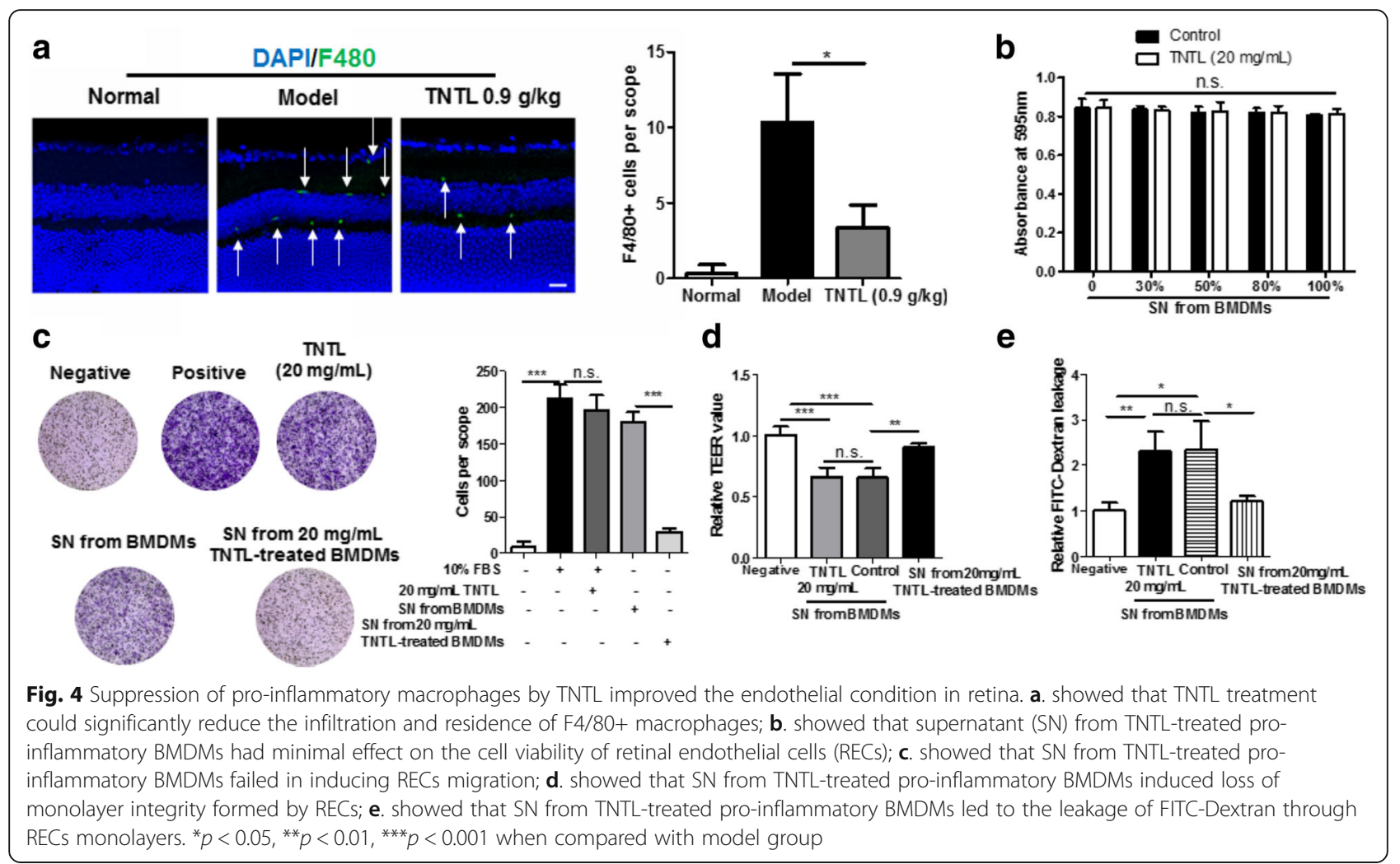

the retina, we conducted the antibody array on serum from mice treated with TNTL and SN collected from pro-inflammatory BMDMs treated with TNTL. The cytokines downregulated by TNTL were highlighted in red while those upregulated by TNTL were highlighted in blue (Fig. 5a \& b). It was shown that TNTL consistently regulated three cyto-

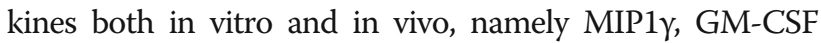
and IL4 (Fig. 5c). Since IL4 level was not consistently regulated in serum or SN by TNTL, expressions of MIP1 $\gamma$ and GM-CSF were further examined in TNTL-treated BMDMs. TNTL treatment showed significant suppression on MIP1 $\gamma$ but had minimal effect on GM-GSF (Fig. 5d). To further identify the critical target molecule, we supplemented the recombinant MIP1 $\gamma$ protein to the SN collected from TNTL-treated BMDMs. Using the modified SN to culture RECs, the inhibitory effect of TNTL on the REC migration was recovered by supplementation of recombinant MIP1y protein (Fig. 5e). Consistently, loss of RECs monolayer integrity along with the increase of FITCdextran leakage was observed in RECs cultured with MIP1 $\gamma$-supplemented SN (Fig. $5 f$ \& g). These data suggested that suppression of MIP1 $\gamma$ release from macrophages by TNTL may be responsible for the prevention of endothelial dysfunction in the diabetic retina.

MIP1 $\gamma$ is a cytokine constitutively secreted by macrophages and myeloid cells [34]. MIP1 $\gamma$ and its receptor CCR1, has been widely reported for their ability in regulating cell motility [35]. To examine the involvement of
MIP1 $/$ CCR1 pathway in the anti-inflammatory effect of TNTL, firstly, we blotted the related molecules within RECs cultured with SN from TNTL-treated BMDMs. It was showed that CCR1 mediated downstream pathways, such as JNK and PI3K/Akt, was less activated when BMDMs were pre-treated by TNTL (Fig. 6a). This claim was further confirmed by qRT-PCR assay, which showed reduced expression of migration/invasion-associated transcription products of MIP1 $\gamma / C C R 1$ pathway (Fig. 6b). Furthermore, migration of RECs provoked by MIP1 $\gamma$ was blocked by CCR1 antagonist J-113863 [36] (Fig. 6c), and loss of monolayer integrity and leakage of FITC-dextran by MIP1 $\gamma$ were reversed by J-113863 (Fig. 6d \& e), Indicating that blocking MIP1 $\gamma / C C R 1$ pathway in endothelial cells may prevent the inflammatory macrophage-induced endothelial dysfunction. These data, combined with other above findings, suggest that inhibition of MIP1 $1 / C C R 1$ axis in retinal microenvironment by TNTL contributed to the inhibition of DR progression.

\section{Discussion}

Insulin therapy remains to be an effective mean for glycemic control in diabetic patients. However, insulin therapy is deemed to be unsuccessful in well controlling the incidence of DR, conversely, acts as one of the contributors of DR [37]. Insulin use is an independent risk factor of DR progression in US adults with diabetes (OR, 3.23; 95\% CI, 1.99-5.26) [38]. The previous study showed that 


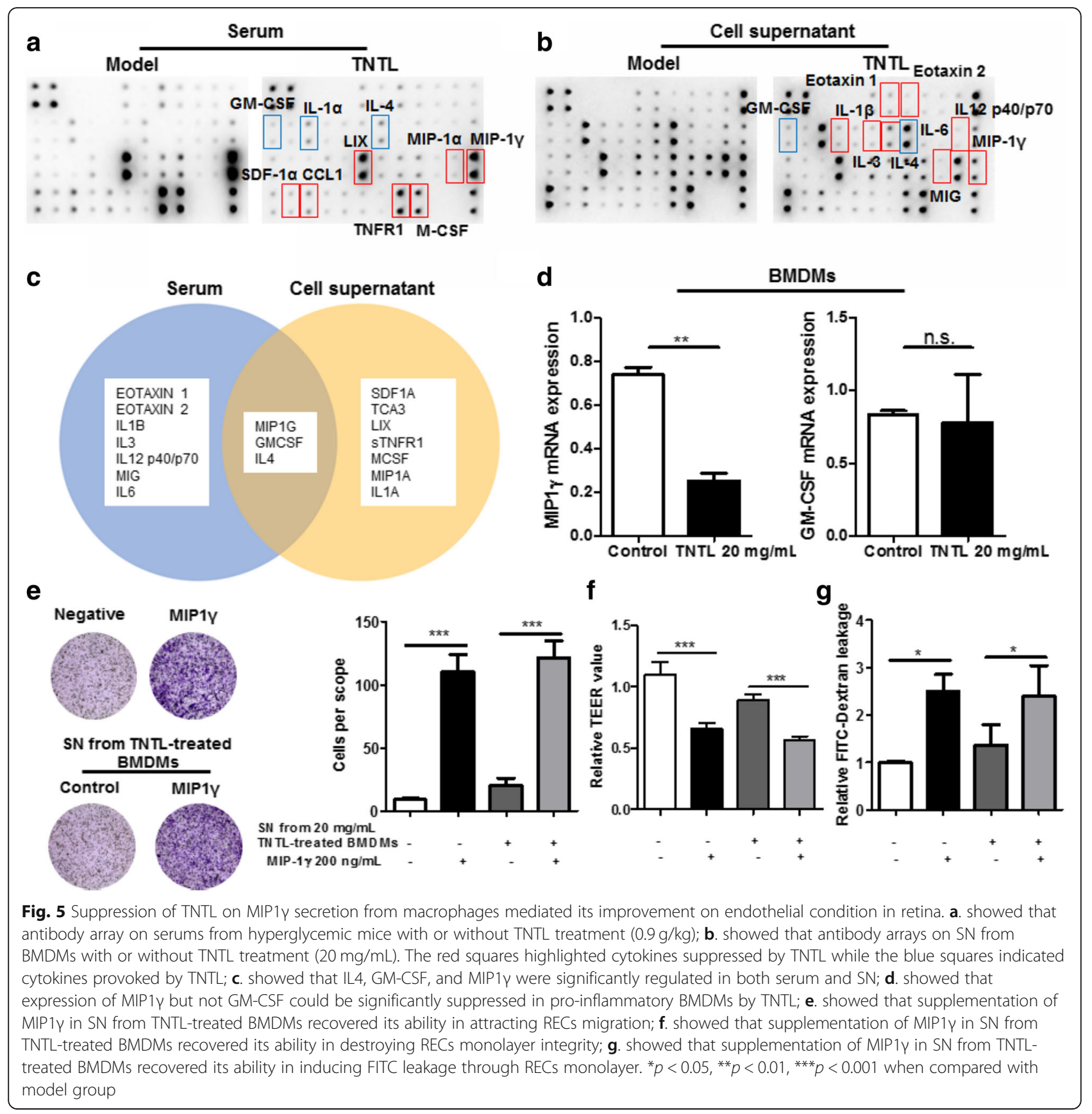

the majority of type II diabetic patients using insulin injection suffered from DR (70\%) compared to those without insulin treatment (39\%) [39]. A meta-analysis on seven cohort studies detected a significant association between insulin usage and increased risk of DR despite existing heterogeneity of retrieved literature [40]. Residual endogenous insulin secretion is associated with both DR prevalence and its severity in Latinos with familial type II diabetes [41]. These previous findings suggest that glycemic control may not be the only critical factor to prevent incidence of DR. We found that TNTL at its high doses may possess anti-hyperglycemic effect, however, improvement on the retina condition by TNTL could be steadily achieved at its low dose as well, which indicated that the effect of TNTL on DR might be independent, at least partially, to its blood glucose-reducing action. Currently, ocular injection of anti-VEGF monoclonal antibody is the main non-surgical approach in treating late-stage DR, and intravitreal corticosteroids injection targeting inflammation has been approved by FDA as an alternative treatment to patients without significant response to anti-VEGF treatment [42]. The 

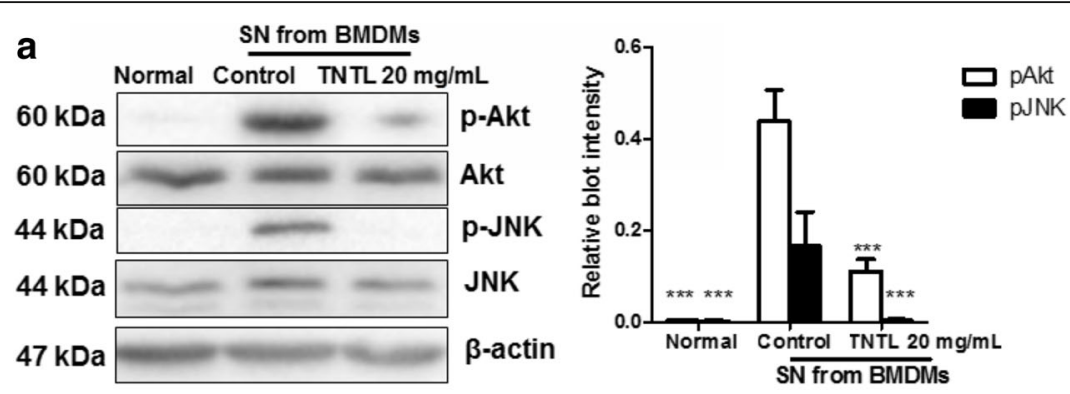

b

MMP-2
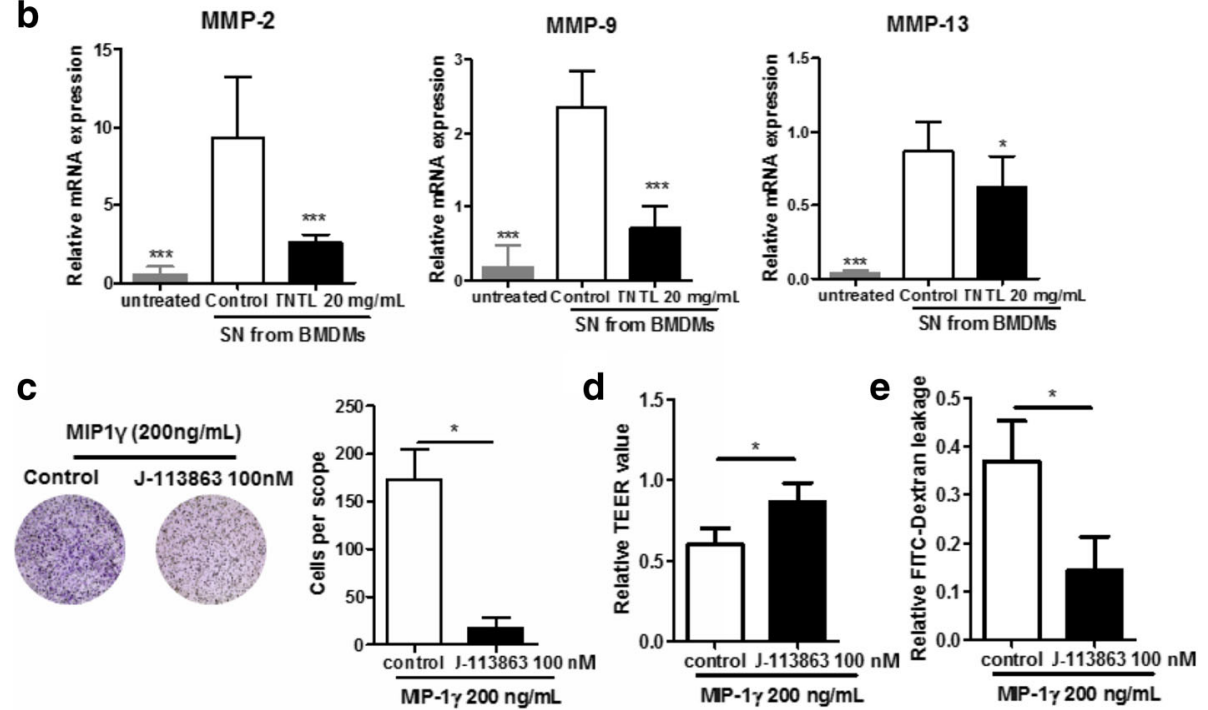

Fig. $6 \mathrm{MIP} 1 \gamma / \mathrm{CCR} 1$ axis in retina endothelial cells contributed to the ameliorative effect of TNTL on endothelial dysfunction. a. showed that CCR1 downstream signalings in RECs cultured with SN from TNTL-treated BMDMs were blunted; $\mathbf{b}$. showed that transcription of migration/invasionassociated genes was not activated in RECs cultured with SN from TNTL-treated BMDMs; $\mathbf{c}$. showed that MIP1Y-induced RECs migration was blocked by the presence of CCR1 antagonist J-113863 (100 nM); $\mathbf{d}$. showed that MIP1Y-induced loss of RECs monolayer integrity was blocked by the presence of CCR1 antagonist J-113863 (100 nM); e. showed MIP1 $y$-induced FITC-Dextran leakage through RECs monolayer was blocked by the presence of CCR1 antagonist J-113863 (100 nM). ${ }^{*} p<0.05,{ }^{* *} p<0.01,{ }^{* * *} p<0.001$ when compared with model group

current protocol for a combination of anti-VEGF and anti-inflammatory agents in treating DR is not available despite several trials to have been conducted [43], probably due to the assumption that frequent vitreous injection may not be practical and do harm to the eye condition, however, an additional benefit of combination treatment is still possible to DR patients. Some pro-inflammatory factors, such as angiopoietin-2, proteinases, CCL2, were suggested to be potential targets [44]. In our study, we found that inflammatory suppression instead of controlling the systemic condition of diabetes might be involved in the effect of TNTL, which may particularly exert a beneficial effect on the normalization of the retina environment by targeting MIP1 $\gamma / C C R 1$ axis. This indicates TNTL as an orally administrated anti-inflammatory agent can benefit retina condition in diabetes, and offers a possibility in the practice of combination treatment of TNTL with intravitreal injection of antiVEGF agents. Indeed, several clinical studies about the efficacy and safety of TNTL on diabetic patients have been undergoing or completed (clinicaltrial.gov registration No. NCT02161276 \& NCT02174042). Findings from our studying combining the clinical observation on efficacy and safety of TNTL may further justify its potential as an adjuvant therapy to intravitreal injection of anti-VEGF in DR treatment.

Although in our study, we found that TNTL exhibited a protective effect against hyperglycemia-induced retinopathy at the dose which it did not reduce blood glucose, it cannot fully conclude that the two actions could be separated. This could occur due to the low sensitivity of the assays but may also be due to the complicated crosstalk of hyperglycemia and inflammation in the mechanism initiating retinopathy during diabetes. It was previously shown that hyperglycemia could significantly provoke inflammation via an oxidative mechanism [45]. However, anti-inflammatory agents have also been proven to reduce blood glucose in diabetes [46]. This suggests that it might be difficult to completely distinguish the effect of anti-hyperglycemia and anti-inflammation in diabetic treatment. Furthermore, whether 
TNTL could control inflammation systematically or specifically in retina remains unclear. Although from in vitro study we confirmed that possible inhibitory effect of TNTL on immune-endothelial cell interaction, the conclusion about the target inhibition on retinal inflammation by TNTL in vivo could be comprised without ruling out the possibility of TNTL in controlling systemic inflammation. Some further studies, for example, to determine whether revoking systemic inflammation could comprise the effect of TNTL, may provide more justifications. Also, identifying active components from TNTL that could pass blood-retina barriers may also help to understand its target specific action.

An opportunity for prevention and treatment of DR by blocking inflammation has been partially evident by clinical observations on the use of corticosteroids in the treatment of proliferative DR. It was observed that intravitreal injection of triamcinolone before laser panretinal photocoagulation could significantly reduce the neovascularization [47] and was associated with reduced risk of proliferative DR worsening [48]. In patients with non-high-risk proliferative $\mathrm{DR}$, intravitreal injection of triamcinolone as an adjuvant therapy could delay the deterioration of visual acuity [49], but this effect could be insignificant in patients with highrisk proliferative DR [50]. This may suggest that the intravitreal corticosteroids treatment could be still controversial. Indeed, several observations also reported that the effect of intravitreal injection of triamcinolone to reduce the rates of progression of proliferative DR was not warranted [51, 52]. Also, the application of corticosteroids faces several shortcomings. Frequent injection is necessary. High incidence of cataract and ocular complications such as cataract formation, IOP, and glaucoma as well as systemic side effects including exacerbation of diabetes, may exclude its prophylactic use in DM patients without retinopathy, as well as therapeutic application in the early stage of DR [53]. Treatment with the nonsteroidal anti-inflammatory drug was proposed, but the clinical study showed that only high dose of aspirin $(900 \mathrm{mg} /$ day) could minimize the development of the early stage of DR [54], while systemic COX-2 inhibitor increased the risk of heart attacks and strokes in DR patients [55]. In our study, we observed that TNTL possessed significant anti-inflammatory effect in DR. TNTL is ann herbal formula that has been used for thousands of years without apparent side effects. The acute and chronic impacts of TNTL on rodents were recently tested, which suggested that TNTL has no profound toxicity to the animals (data not shown). The present observation supported that TNTL, with a mechanism tar-

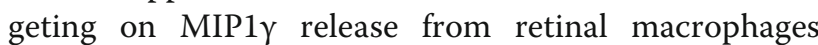
that can further suppress endothelial activation, can be an alternative treatment for DR, and a potential lead for the discovery of novel anti-inflammatory agents that are suitable for DR treatment.

We noticed that in addition to pathways-related to inflammation and immune system, TNTL might also target on PI3K/Akt pathway. It was previously found that regulation on the PI3K/Akt pathway may play an essential role in the treatment of diabetic retinopathy. Sheikpranbabu et al. suggested that inhibition of PI3K/ Akt could significantly suppress vascular permeability by improving junction protein expression [56]; controversially, activating PI3K/Akt signaling in retinal neural cells protected against hyperlipidemia-induced oxidative stress and cell death [57]. More interestingly, several previous studies were suggesting that PI3K/Akt could serve as important signaling in the activation of retinal pigment cells during disease progression. Inhibition of PI3K/Akt by (-)-epigallocatechin gallate could significantly inhibit the migration and adhesion of retinal pigment cells [58]. Interestingly, a few studies also suggested that PI3K/Akt may be involved in the inflammation-related retinal pigment cell activation. A pro-inflammatory factor high mobility group B1 could induce secretion of

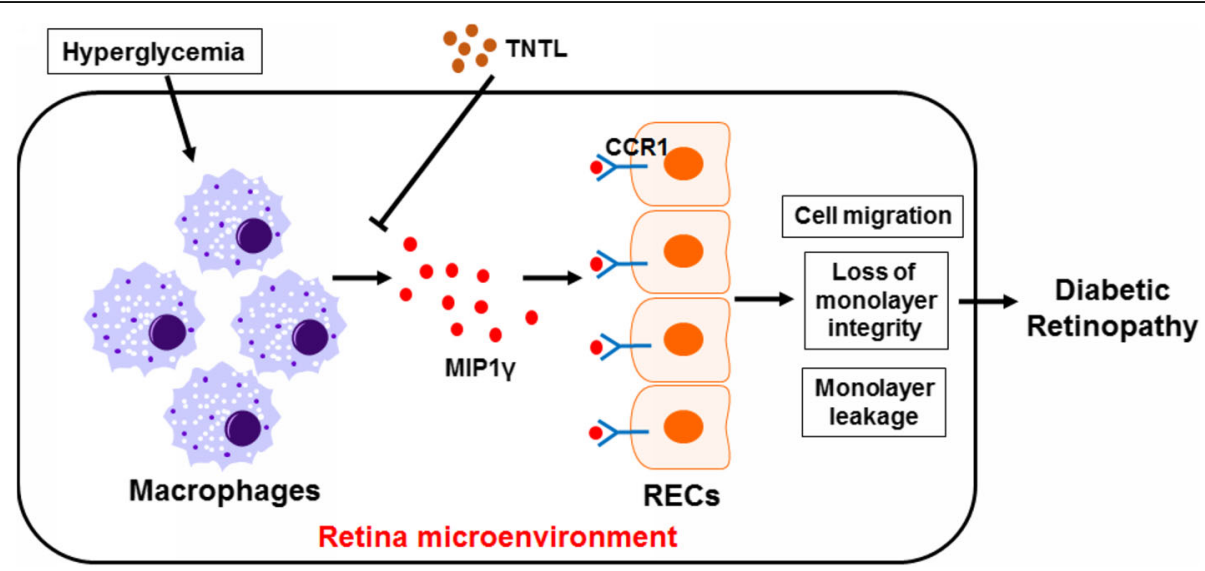

Fig. 7 Proposed mechanism underlying the action of TNTL in treating DR 
angiogenic and fibrogenic factors in retinal pigment cells through PI3K/Akt activation [59]. High glucose may cause secretion of pro-inflammatory cytokines from retinal pigment cells, which could be related to PI3K/Akt activation [60]. These suggest that regulating PI3K/Akt alone or in combination with anti-inflammatory treatment may be a novel approach in DR management.

We found that macrophage-secreting MIP1 $\gamma$ may mediate the inhibitory effect of TNTL on endothelial dysfunction. The role of MIP1 $\gamma$ in the initiation and progression of DR has yet been understood, however, as a well-known small cytokine secreted by macrophages and myeloid cells, MIP1y induced movement and infiltration of macrophages during inflammation [61]. Apart from its role as a macrophage attractant, MIP1 $\gamma$ was found to promote and maintain the differentiation and survival of osteoclasts in osteoclastogenesis [62, 63], which indicates its involvement in various human diseases. The primary receptor of MIP1 $\gamma$ on the cellular surface is CCR1, which was found to be expressed in different types of cells, including endothelial cells [64]. Binding of ligands to CCR1 activates the intracellular signaling and induces migration of endothelial cells and live capillaries without affecting its viability and proliferation [65, 66], which in turn leads to neovascularization and angiogenesis [64]. Thus, CCR1 activation in mediating endothelial cell migration without affecting its viability supported our observations that TNTL-treated SN lacking MIP1y could influence RECs migration but had minimal effect on the cell survival compared with control SN with MIP1y. Further observation showed that matrix metalloproteinases (MMPs) expression in RECs cultured with TNTL-treated BMDMs derived SN was reduced. Interestingly, it was previously found that both MIP1Y stimulation and CCR1 activation induce MMPs and promote cell migration and invasion [67, 68], and this effect of MIP1 $\gamma$ was blocked by the presence of CCR1 inhibitor as observed in our study, suggesting that MIP1 $\gamma / C C R 1$ axis play an essential role in mediating the activation of cell migration/invasion-associated signaling in endothelial cells. Compared with the application of CCR1 inhibitor in blocking DR progression with the possibility of side effects in animal and human, the strategy targeting MIP1Y to inhibit activation of CCR1-associated signaling in retinal endothelial cells may be potential to strengthen and diversify treatments against DR progression.

\section{Conclusion}

In conclusion, in this study, we explore the novel therapeutic target of diabetic retinopathy in the intervention of a botanical formula TNTL via transcriptomic analysis in combination with protein array. Consistent quality of TNTL extract was validated by its similar biological activity on hyperglycemia with that reported in previous studies. At its doses without significantly reducing blood glucose in hyperglycemic mice, TNTL was able to ameliorate the initiation and progression of DR, as evidenced by reduced BRB leakage, retinal neovascularization and restored retinal ganglion population. We performed transcriptomic analysis on the gene expression in the retina of hyperglycemic mice with or without TNTL treatment and found that TNTL may inhibit inflammation in the retinal microenvironment. The anti-inflammatory effect of TNTL was validated by experimental observations of reduced infiltration of pro-inflammatory macrophages in the retina. Suppression of inflammation in macrophages reduced the secretion of factors that promoted migration and loss of endothelial cells integrity. Also, antibody array analysis suggested that MIP1 $\gamma$, whose secretion by macrophage was inhibited by TNTL, may be responsible for the therapeutic effects. Supplementation of MIP1 $\gamma$ neutralized the effect of TNTL on endothelial dysfunction. CCR1-associated pathway in endothelial cells might be responsible for the inhibitory effect of TNTL on MIP1 $\gamma$-induced disorders in endotheliocytes (Fig. 7). Our study suggested that TNTL may improve DR by targeting MIP1 $\gamma / C C R 1$ axis to reduce inflammation in the retinal microenvironment.

\section{Abbreviations}

BMDMs: Bone marrow-derived macrophages; BP: Biological process; BRB: Blood-retina barrier; CC: Cellular components; CCR1: C-C chemokine receptor type 1; Cl: Confidence interval; COX-2: Cyclooxygenase-2; CRP: Creactive protein; DM: Diabetes mellitus; DME: Diabetic macular edema;

DR: Diabetic retinopathy; ECL: Enhanced Chemiluminescence; FBG: Fasting blood glucose; GMP: Good manufacturing practice; GO: Gene ontology; GSEA: Gene set enrichment analysis; HbA1c: Hemoglobin A1c; HIF-

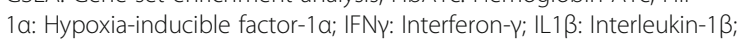
IL4: Interleukin-4; IL6: Interleukin-6; IL8: Interleukin-8; IOP: Intraocular pressure; JNK: c-Jun N-terminal kinase; KEGG: Kyoto Encyclopedia of Genes and Genomes; LPS: Lipopolysaccharide; MCP-1: Monocyte chemoattractant protein-1; M-CSF: Granulocyte-macrophage colony-stimulating factor; MCSF: Macrophage-colony stimulating factor; MF: Molecular functions; MIP1Y: Macrophage inflammatory protein-1 Y; OR: Odds ratio; PI3K: Phosphoinositide 3-kinase; RBG: Random blood glucose; RECs: Retinal Endothelial Cells; RIPA: Radioimmunoprecipitation assay; SDS-PAGE: Sodium dodecyl sulphate-polyacrylamide gel electrophoresis; SIL2R: Soluble interleukin-2 receptor; SN: Supernatant; STZ: Streptozotocin; TBST: Trisbuffered saline-Tween 20; TEER: Transepithelial/Transendothelial Electrical Resistance; TNFa: Tumor necrosis factor-a; TNTL: Tang-Ning-Tong-Luo; VEGF: Vascular endothelial growth factor

\section{Acknowledgments}

Authors would like to express their thanks to Mr. Keith Wong, Ms. Cindy Lee, Mr. Alex Shek, Mr. Eugene Chan and the Faculty Core Facility of Li Ka Shing Faculty of Medicine, The University of Hong Kong, for their technical support.

\section{Authors' contributions}

NW performed the animal and cell studies, analyzed the data, and drafted the manuscript. ZC and YX participated in the animal study. SL and HYT participated in the cell study. WX involved in the extraction of TNTL. YF conceived the idea, designed the experiment, analyzed the data, and drafted the manuscript. All authors read and approved the final manuscript.

\section{Funding}

This research was partially supported by the Research Council of the University of Hong Kong (project codes: 104003422, 104004092 and 104004460), Wong's donation (project code: 200006276), a donation from 
the Gaia Family Trust of New Zealand (project code: 200007008), a contract research project (project code: 260007482), the Research Grants Committee (RGC) of Hong Kong, HKSAR (Project Codes: 740608, 766211 and 17152116) and Health and Medical Research Fund (15162961).

\section{Availability of data and materials}

The datasets used and/or analyzed during the current study are available from the corresponding author on reasonable request.

\section{Ethics approval and consent to participate}

Protocols of animal study were reviewed and approved by the Committee on the Use of Live Animals in Teaching and Research (CULATR) of the University of Hong Kong.

\section{Consent for publication}

Not applicable.

\section{Competing interests}

Dr. Feng Yibin received grant support from Bailing Pharmaceutical Group Co. (Guizhou, China), who provided the standard extract of TNTL for the whole study. Other authors declare no conflict of interest.

\section{Author details}

'School of Chinese Medicine, The University of Hong Kong, 1/F, 10 Sassoon

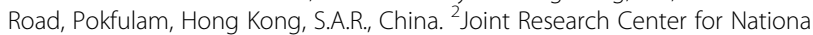
and Local Miao Drug, Anshun, Guizhou Province, People's Republic of China.

\section{Received: 14 March 2019 Accepted: 15 July 2019}

\section{Published online: 22 July 2019}

\section{References}

1. Pascolini D, Mariotti SP. Global estimates of visual impairment: 2010. Br J Ophthalmol. 2012;96:614-8.

2. Sivaprasad S, Gupta B, Crosby-Nwaobi R, Evans J. Prevalence of diabetic retinopathy in various ethnic groups: a worldwide perspective. Surv Ophthalmol. 2012:57:347-70.

3. Gangwani RA, Lian JX, McGhee SM, Wong D, Li KK. Diabetic retinopathy screening: global and local perspective. Hong Kong Med J. 2016;22:486-95.

4. Gupta N, Mansoor S, Sharma A, Sapkal A, Sheth J, Falatoonzadeh P, Kuppermann B, Kenney M. Diabetic retinopathy and VEGF. Open Ophthalmol J. 2013;7:4-10.

5. Penn JS, Madan A, Caldwell RB, Bartoli M, Caldwell RW, Hartnett ME. Vascular endothelial growth factor in eye disease. Prog Retin Eye Res. 2008; 27:331-71

6. Group AS, Group AES, Chew EY, Ambrosius WT, Davis MD, Danis RP, Gangaputra S, Greven CM, Hubbard L, Esser BA, et al. Effects of medical therapies on retinopathy progression in type 2 diabetes. N Engl J Med. 2010;363:233-44.

7. Capitao M, Soares R. Angiogenesis and inflammation crosstalk in diabetic retinopathy. J Cell Biochem. 2016;117:2443-53.

8. Petrovic MG, Korosec P, Kosnik M, Hawlina M. Association of preoperative vitreous IL-8 and VEGF levels with visual acuity after vitrectomy in proliferative diabetic retinopathy. Acta Ophthalmol. 2010;88:e311-6.

9. Roy MS, Janal MN, Crosby J, Donnelly R. Inflammatory biomarkers and progression of diabetic retinopathy in African Americans with type 1 diabetes. Invest Ophthalmol Vis Sci. 2013;54:5471-80.

10. Doganay S, Evereklioglu C, Er H, Turkoz Y, Sevinc A, Mehmet N, Savli H. Comparison of serum NO, TNF-alpha, IL-1 beta, sIL-2R, IL-6 and IL-8 levels with grades of retinopathy in patients with diabetes mellitus. Eye (Lond). 2002;16:163-70.

11. $\mathrm{Xu} \mathrm{H}$, Chen M. Diabetic retinopathy and dysregulated innate immunity. Vis Res. 2017;139:39-46

12. Lee R, Wong TY, Sabanayagam C. Epidemiology of diabetic retinopathy, diabetic macular edema and related vision loss. Eye Vis (Lond). 2015;2:17.

13. Sorrentino FS, Allkabes M, Salsini G, Bonifazzi C, Perri P. The importance of glial cells in the homeostasis of the retinal microenvironment and their pivotal role in the course of diabetic retinopathy. Life Sci. 2016;162:54-9.

14. Wang L, Wang N, Tan HY, Zhang Y, Feng Y. Protective effect of a Chinese medicine formula he-Ying-Qing-re formula on diabetic retinopathy. J Ethnopharmacol. 2015;169:295-304.
15. Li Y, Andereggen L, Yuki K, Omura K, Yin Y, Gilbert HY, Erdogan B, Asdourian MS, Shrock C, de Lima S, et al. Mobile zinc increases rapidly in the retina after optic nerve injury and regulates ganglion cell survival and optic nerve regeneration. Proc Natl Acad Sci U S A. 2017:114:E209-18.

16. Liu R, Wang Y, Pu M, Gao J. Effect of alpha lipoic acid on retinal ganglion cell survival in an optic nerve crush model. Mol Vis. 2016;22:1122-36.

17. Xia J, Gill EE, Hancock RE. NetworkAnalyst for statistical, visual and networkbased meta-analysis of gene expression data. Nat Protoc. 2015;10:823-44.

18. Xia J, Benner MJ, Hancock RE. NetworkAnalyst--integrative approaches for protein-protein interaction network analysis and visual exploration. Nucleic Acids Res. 2014;42:W167-74.

19. Xia J, Lyle NH, Mayer ML, Pena OM, Hancock RE. INVEX--a web-based tool for integrative visualization of expression data. Bioinformatics. 2013; 29:3232-4.

20. Xia J, Fjell CD, Mayer ML, Pena OM, Wishart DS, Hancock RE. INMEX--a webbased tool for integrative meta-analysis of expression data. Nucleic Acids Res. 2013:41:W63-70.

21. Tan HY, Wang N, Man K, Tsao SW, Che CM, Feng Y. Autophagy-induced RelB/p52 activation mediates tumour-associated macrophage repolarisation and suppression of hepatocellular carcinoma by natural compound baicalin Cell Death Dis. 2015:6:e1942.

22. Srinivasan B, Kolli AR, Esch MB, Abaci HE, Shuler ML, Hickman JJ. TEER measurement techniques for in vitro barrier model systems. J Lab Autom. 2015;20:107-26.

23. Cheng L, Song J, Li G, Liu Y, Wang Y, Meng X, Sun G, Sun X. Effects of the Tangningtongluo formula as an alternative strategy for diabetics via upregulation of insulin receptor substrate-1. Mol Med Rep. 2017;16:703-9.

24. Cheng L, Meng XB, Lu S, Wang TT, Liu Y, Sun GB, Sun XB. Evaluation of hypoglycemic efficacy of tangningtongluo formula, a traditional Chinese Miao medicine, in two rodent animal models. J Diabetes Res. 2014;2014:745419.

25. Valencia WM, Florez $\mathrm{H}$. How to prevent the microvascular complications of type 2 diabetes beyond glucose control. BMJ. 2017:356:16505.

26. Zhang C, Xu Y, Tan HY, Li S, Wang N, Zhang Y, Feng Y. Neuroprotective effect of he-Ying-Qing-re formula on retinal ganglion cell in diabetic retinopathy. J Ethnopharmacol. 2018;214:179-89.

27. Sippl C, Bosserhoff AK, Fischer D, Tamm ER. Depletion of optineurin in RGC5 cells derived from retinal neurons causes apoptosis and reduces the secretion of neurotrophins. Exp Eye Res. 2011:93:669-80.

28. Vuong HE, Perez de Sevilla Muller L, Hardi CN, McMahon DG, Brecha NC. Heterogeneous transgene expression in the retinas of the TH-RFP, TH-Cre, TH-BAC-Cre and DAT-Cre mouse lines. Neuroscience. 2015;307:319-37.

29. Rodriguez AR, de Sevilla Muller LP, Brecha NC. The RNA binding protein RBPMS is a selective marker of ganglion cells in the mammalian retina. J Comp Neurol. 2014;522:1411-43.

30. Wang Y, Wang W, Liu J, Huang X, Liu R, Xia H, Brecha NC, Pu M, Gao J. Protective effect of ALA in crushed optic nerve cat retinal ganglion cells using a new marker RBPMS. PLoS One. 2016;11:e160309.

31. Obara EA, Hannibal J, Heegaard S, Fahrenkrug J. Loss of Melanopsinexpressing retinal ganglion cells in patients with diabetic retinopathy. Invest Ophthalmol Vis Sci. 2017;58:2187-92.

32. Roy S, Kern TS, Song B, Stuebe C. Mechanistic insights into pathological changes in the diabetic retina: implications for targeting diabetic retinopathy. Am J Pathol. 2017:187:9-19.

33. Robertson MJ, Erwig LP, Liversidge J, Forrester JV, Rees AJ, Dick AD. Retinal microenvironment controls resident and infiltrating macrophage function during uveoretinitis. Invest Ophthalmol Vis Sci. 2002;43:2250-7.

34. Hara T, Bacon KB, Cho LC, Yoshimura A, Morikawa Y, Copeland NG, Gilbert DJ, Jenkins NA, Schall TJ, Miyajima A. Molecular cloning and functional characterization of a novel member of the C-C chemokine family. J Immunol. 1995:155:5352-8.

35. Lean JM, Murphy C, Fuller K, Chambers TJ. CCL9/MIP-1gamma and its receptor CCR1 are the major chemokine ligand/receptor species expressed by osteoclasts. J Cell Biochem. 2002;87:386-93.

36. Amat M, Benjamim CF, Williams LM, Prats N, Terricabras E, Beleta J, Kunkel SL, Godessart N. Pharmacological blockade of CCR1 ameliorates murine arthritis and alters cytokine networks in vivo. Br J Pharmacol. 2006;149:666-75.

37. Wat N, Wong RL, Wong IY. Associations between diabetic retinopathy and systemic risk factors. Hong Kong Med J. 2016;22:589-99.

38. Zhang X, Saaddine JB, Chou CF, Cotch MF, Cheng YJ, Geiss LS, Gregg EW, Albright AL, Klein BE, Klein R. Prevalence of diabetic retinopathy in the United States, 2005-2008. JAMA. 2010;304:649-56. 
39. Klein R, Klein BE, Moss SE, Davis MD, DeMets DL. The Wisconsin epidemiologic study of diabetic retinopathy. III. Prevalence and risk of diabetic retinopathy when age at diagnosis is 30 or more years. Arch Ophthalmol. 1984;102:527-32.

40. Zhao C, Wang W, Xu D, Li H, Li M, Wang F. Insulin and risk of diabetic retinopathy in patients with type 2 diabetes mellitus: data from a metaanalysis of seven cohort studies. Diagn Pathol. 2014;9:130.

41. Kuo JZ, Guo X, Klein R, Klein BE, Weinreb RN, Genter P, Hsiao FC, Goodarzi MO, Rotter JI, Chen YD, Ipp E. Association of fasting insulin and C peptide with diabetic retinopathy in Latinos with type 2 diabetes. BMJ Open Diabetes Res Care. 2014;2:e000027.

42. Lattanzio R, Cicinelli MV, Bandello F. Intravitreal steroids in diabetic macular edema. Dev Ophthalmol. 2017;60:78-90.

43. Mehta H, Hennings C, Gillies MC, Nguyen V, Campain A, Fraser-Bell S. Antivascular endothelial growth factor combined with intravitreal steroids for diabetic macular oedema. Cochrane Database Syst Rev. 2018;4:CD011599.

44. Rangasamy S, McGuire PG, Das A. Diabetic retinopathy and inflammation: novel therapeutic targets. Middle East Afr J Ophthalmol. 2012;19:52-9.

45. Esposito K, Nappo F, Marfella R, Giugliano G, Giugliano F, Ciotola M, Quagliaro L, Ceriello A, Giugliano D. Inflammatory cytokine concentrations are acutely increased by hyperglycemia in humans: role of oxidative stress. Circulation. 2002;106:2067-72.

46. Pollack RM, Donath MY, LeRoith D, Leibowitz G. Anti-inflammatory agents in the treatment of diabetes and its vascular complications. Diabetes Care. 2016;39(Suppl 2):S244-52.

47. Bandello F, Polito A, Pognuz DR, Monaco P, Dimastrogiovanni A, Paissios J. Triamcinolone as adjunctive treatment to laser panretinal photocoagulation for proliferative diabetic retinopathy. Arch Ophthalmol. 2006;124:643-50.

48. Bressler SB, Qin H, Melia M, Bressler NM, Beck RW, Chan CK, Grover S, Miller DG. Diabetic retinopathy clinical research $\mathrm{N}$ : exploratory analysis of the effect of intravitreal ranibizumab or triamcinolone on worsening of diabetic retinopathy in a randomized clinical trial. JAMA Ophthalmol. 2013;131:1033-40

49. Kaderli B, Avci R, Gelisken O, Yucel AA. Intravitreal triamcinolone as an adjunct in the treatment of concomitant proliferative diabetic retinopathy and diffuse diabetic macular oedema. Combined IVTA and laser treatment for PDR with CSMO. Int Ophthalmol. 2005;26:207-14.

50. Mirshahi A, Shenazandi H, Lashay A, Faghihi H, Alimahmoudi A, Dianat S. Intravitreal triamcinolone as an adjunct to standard laser therapy in coexisting high-risk proliferative diabetic retinopathy and clinically significant macular edema. Retina. 2010;30:254-9.

51. Bressler NM, Edwards AR, Beck RW, Flaxel CJ, Glassman AR, Ip MS, Kollman C, Kuppermann BD, Stone TW. Diabetic retinopathy clinical research N exploratory analysis of diabetic retinopathy progression through 3 years in a randomized clinical trial that compares intravitreal triamcinolone acetonide with focal/grid photocoagulation. Arch Ophthalmol. 2009;127:1566-71.

52. Takamura $Y$, Shimura M, Katome T, Someya H, Sugimoto M, Hirano T, Sakamoto T, Gozawa M, Matsumura T, Inatani M. Writing committee of Japan-clinical retina research T: effect of intravitreal triamcinolone acetonide injection at the end of vitrectomy for vitreous haemorrhage related to proliferative diabetic retinopathy. Br J Ophthalmol. 2018;102:1351-7.

53. Kastelan S, Tomic M, Gverovic Antunica A, Salopek Rabatic J, Ljubic S. Inflammation and pharmacological treatment in diabetic retinopathy. Mediat Inflamm. 2013;2013:213130.

54. Effects of aspirin treatment on diabetic retinopathy. ETDRS report number 8 . Early Treatment Diabetic Retinopathy Study Research Group. Ophthalmology. 1991;98:757-65.

55. Kim SJ, Flach AJ, Jampol LM. Nonsteroidal anti-inflammatory drugs in ophthalmology. Surv Ophthalmol. 2010;55:108-33.

56. Sheikpranbabu S, Haribalaganesh R, Lee KJ, Gurunathan S. Pigment epithelium-derived factor inhibits advanced glycation end products-induced retinal vascular permeability. Biochimie. 2010;92:1040-51.

57. Yan PS, Tang S, Zhang HF, Guo YY, Zeng ZW, Wen Q. Nerve growth factor protects against palmitic acid-induced injury in retinal ganglion cells. Neural Regen Res. 2016;11:1851-6.

58. Chan CM, Huang JH, Chiang HS, Wu WB, Lin HH, Hong JY, Hung CF. Effects of (-)-epigallocatechin gallate on RPE cell migration and adhesion. Mol Vis. 2010;16:586-95.

59. Chang YC, Lin CW, Hsieh MC, Wu HJ, Wu WS, Wu WC, Kao YH. High mobility group B1 up-regulates angiogenic and fibrogenic factors in human retinal pigment epithelial ARPE-19 cells. Cell Signal. 2017:40:248-57.
60. Ran Z, Zhang Y, Wen X, Ma J. Curcumin inhibits high glucoseinduced inflammatory injury in human retinal pigment epithelial cells through the ROSPI3KJAKT/mTOR signaling pathway. Mol Med Rep. 2019;19:1024-31.

61. Niu S, Bian Z, Tremblay A, Luo Y, Kidder K, Mansour A, Zen K, Liu Y. Broad infiltration of macrophages leads to a Proinflammatory state in Streptozotocin-induced hyperglycemic mice. J Immunol. 2016;197:3293-301.

62. Okamatsu Y, Kim D, Battaglino R, Sasaki H, Spate U, Stashenko P. MIP-1 gamma promotes receptor-activator-of-NF-kappa-B-ligand-induced osteoclast formation and survival. J Immunol. 2004;173:2084-90.

63. Yang M, Mailhot G, MacKay CA, Mason-Savas A, Aubin J, Odgren PR. Chemokine and chemokine receptor expression during colony stimulating factor-1-induced osteoclast differentiation in the toothless osteopetrotic rat: a key role for CCL9 (MIP-1gamma) in osteoclastogenesis in vivo and in vitro. Blood. 2006;107:2262-70.

64. Hwang J, Son KN, Kim CW, Ko J, Na DS, Kwon BS, Gho YS, Kim J. Human CC chemokine CCL23, a ligand for CCR1, induces endothelial cell migration and promotes angiogenesis. Cytokine. 2005;30:254-63.

65. Strasly M, Doronzo G, Cappello P, Valdembri D, Arese M, Mitola S, Moore P, Alessandri G, Giovarelli M, Bussolino F. CCL16 activates an angiogenic program in vascular endothelial cells. Blood. 2004;103:40-9.

66. Hwang J, Kim CW, Son KN, Han KY, Lee KH, Kleinman HK, Ko J, Na DS, Kwon BS, Gho YS, Kim J. Angiogenic activity of human CC chemokine CCL15 in vitro and in vivo. FEBS Lett. 2004;570:47-51.

67. Son KN, Hwang J, Kwon BS, Kim J. Human CC chemokine CCL23 enhances expression of matrix metalloproteinase-2 and invasion of vascular endothelial cells. Biochem Biophys Res Commun. 2006;340:498-504.

68. Swamydas M, Ricci K, Rego SL, Dreau D. Mesenchymal stem cell-derived CCL-9 and CCL-5 promote mammary tumor cell invasion and the activation of matrix metalloproteinases. Cell Adhes Migr. 2013;7:315-24.

\section{Publisher's Note}

Springer Nature remains neutral with regard to jurisdictional claims in published maps and institutional affiliations.
Ready to submit your research? Choose BMC and benefit from:

- fast, convenient online submission

- thorough peer review by experienced researchers in your field

- rapid publication on acceptance

- support for research data, including large and complex data types

- gold Open Access which fosters wider collaboration and increased citations

- maximum visibility for your research: over $100 \mathrm{M}$ website views per year

At BMC, research is always in progress.

Learn more biomedcentral.com/submissions 